Volume 10, Issue 4, July-August 2019, pp.205-215, Article ID: IJM 1004020

Available online at http://iaeme.com/Home/issue/IJM? Volume $=10 \&$ Issue $=4$

Journal Impact Factor (2019): 9.6780 (Calculated by GISI) www.jifactor.com ISSN Print: 0976-6502 and ISSN Online: 0976-6510

\title{
INTENTION TO ADOPT E-HRM (ELECTRONIC - HUMAN RESOURCE MANAGEMENT) IN INDIAN MANUFACTURING INDUSTRY: AN EMPIRICAL STUDY USING TECHNOLOGY ACCEPTANCE MODEL (TAM)
}

\author{
Dr. Arunangshu Giri* \\ Associate Professor, School of Management \& Social Science, \\ Haldia Institute of Technology, Haldia, West Bengal, India. \\ Dr. Pradip Paul \\ Senior Manager (Retail Sales), Haldia Divisional Office, \\ Indian Oil Corporation Ltd., Haldia, West Bengal, India. \\ Satakshi Chatterjee \\ Assistant Professor, Department of Pharmaceutical Management, \\ Haldia Institute Management, Haldia, West Bengal, India.

\section{Manigrib Bag} \\ Assistant Professor, School of Management \& Social Science, \\ Haldia Institute of Technology, Haldia, West Bengal, India \\ Abanti Aich \\ Assistant Professor, Department of Science and Management, \\ Haldia Institute of Health Sciences, Haldia, West Bengal, India. \\ Intention to Adopt e-HRM (Electronic - Human Resource Management) in Indian \\ Manufacturing Industry: An Empirical Study Using Technology Acceptance Model (TAM)
}

\begin{abstract}
E-HRM is the adoption and implementation of the web enabled technology to the various HR processes. It directly contributes to the organizational effectiveness and it creates various alternatives to get the work done in a relatively shorter period of time. Limited research has been done in this field and its full potential is yet to be anticipated as it is still growing at a remarkable pace. This research paper aims at quantitatively analyzing the intention of adopting the E-HRM technology by HR Professionals with the help of the TAM (Technology Acceptance Model) model specifically in the manufacturing sector of India. The responses of 200 HR Professionals were collected
\end{abstract}


through convenience sampling method by the help of structure questionnaires distributed to selected manufacturing companies with different categories in India. To analyze the impact of different identified factors on Attitude towards Technology Acceptance and Intention to use, Structural Equation Modelling (SEM) using AMOS Software has been executed in this paper. Adoption of E-HRM technology in the manufacturing industry will help HR Professionals to do their work in an effective manner and it will also help them in handling immense work pressure.

Keywords: e-HRM; TAM model; Intention to use, Indian Manufacturing Industry, Structural Equation Modelling (SEM)

Cite this Article: Dr. Arunangshu Giri, Dr. Pradip Paul, Satakshi Chatterjee, Manigrib Bag and Abanti Aich, Intention to Adopt E-Hrm (Electronic - Human Resource Management) in Indian Manufacturing Industry: an Empirical Study Using Technology Acceptance Model (Tam), International Journal of Management, 10 (4), 2019, pp. 205 -215 .

http://iaeme.com/Home/issue/IJM?Volume=10\&Issue $=4$

\section{INTRODUCTION}

Information and Communication Technologies are continuously evolving and embedding itself in the modern society. From an industrial point of view, the internal service providers, as for example, the HR department, are also adapting to these new technologies in order to meet the volatile demands of the market (Gloet \& Berrell, 2003). Thus, the adoption of ICT (Information and communications technology) by the HR department of the various organizations in order to increase their organizational effectiveness is known as e-HRM. The function of e-HRM is to create social as well as intellectual capital in the organization by the enhancement of knowledge amongst the employees (Lengnick-Hall \& Moritz, 2003). Accordingly, the administrative functions of the HR department might be improved drastically. Technology can be used to facilitate various HR processes such as strategic contribution, personal credibility as well as HR delivery on time. The HR department can act as a facilitator and an agent of change in the organization and help the employees to suitably transition to this change in a smooth manner without any hitches. The HR department should also look after the fact that all the policies; processes as well as practices must complement the overall strategy followed by the organization. All these functions stated above can be covered through the adoption and subsequently implementation of the proper technology. The adoption of the technology can be explained in accordance to the TAM Model.

\section{LITERATURE REVIEW}

The TAM (Technology Acceptance Model) was developed by Davis, in the year 1989 and it was further modified by Venkatesh, in the year 2003 (Venkatesh \& Bala, 2008). This model, basically, helps to understand the acceptance level as the attitude towards the IT systems adopted by the organisation. This model focuses upon two factors which are the perceived usefulness of the technology as well as the perceived ease of use of the said technology. These two factors are related to the employees of the organizations and thus, internal in nature. They are based on the perception of these employees when they are asked to utilize the technology. A positive perception on their part would lead them to have a positive intention to utilize the technology which would lead to the actual system use (Dosajh \& Sujlana, 2012). 


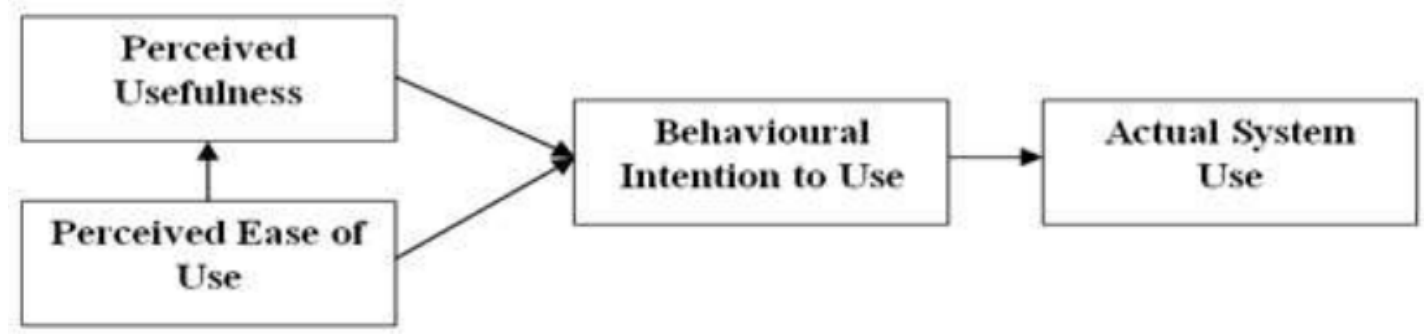

Source: Davis et al. (1989), Venkatesh et al. (2008)

Figure 1: Technology Acceptance Model (TAM)

Perceived usefulness is taken as one of the external factors which affect the behavioural intention of the employees. The relationship between the two factors of perceived usefulness and behavioural intention has been studied and it was seen that the behavioural intention of the recipients is most significantly influenced by their perception of the level of usefulness of the technology. It has been observed that the perceived usefulness is a crucial factor which urges them to use the e-learning management systems which inculcates the behavioural intention of using that particular technology (Ho, 2010). Perceived ease of use is regarded as another external factor which affects the behavioural intention of the respondents. Complicated systems which are hard to understand are not preferred by the respondents as they lose interest quickly and a negative attitude towards that particular technology is built up in their minds. In a similar manner, the perception of ease of use towards a particular technology is beneficial to build a positive impression on the minds of the respondents. This positive impression would help in the building of a positive behavioural intention to use that particular technology instead of transgressing to the manual way of work (Lin, et al., 2011). The previous two factors, that is, perceived usefulness and perceived ease of use are mainly focusing on the individual perspective of the employees. However, the organizational perspective should be considered as well. This is because the employees are ultimately working for the growth of the organization on a whole and this growth will lead to their individual growth also in the long run. Thus, the expected benefits in the organizational context are taken as well. The government can also come up with certain models which would integrate the private firms as well through the use of PPP models and their sole objective would be to come up with certain social as well as economic benefits for the people (Liang, 2017). Attitude of the respondents significantly affects the intention to adopt the technology (Robey, 1979 \& Swanson, 1982). The TAM model depicts that the perceived ease of use and perceived usefulness of a technology affects the attitude of the respondents which further transforms into a behavioral intention to use the technology whenever required. Thus, E-HRM technologies must be adopted as such which will be desirable to use by the HR Professionals and it would result in a pleasant experience for them as well. In order to do this, the background of technology-users should be taken into consideration and also the type of work that needs to be done. Attitude is considered as a passive urge. Until and unless the attitude directly influences the behaviour of the respondents, it does not have any significance. Hence, the respondents must develop an intention on their own to utilize the technology at hand. It is an intrinsic factor which might be influenced by several extrinsic factors (Thiruselvi, et al., 2013). The actual usage of the technology is the main goal of any organisation. This would result in various effective and efficient processes in the long run. The expectations of the employees must be met with. Thus, the usage level would determine the overall acceptance level of the particular technology. 


\section{HYPOTHESES AND RESEARCH MODEL}

H1: 'Perceived Usefulness of e-HRM' positively influences 'Attitude towards using eHRM' in Manufacturing Industry.

H2: 'Perceived Ease of Use e-HRM' positively influences 'Attitude towards using e-HRM' in Manufacturing Industry.

H3: 'Expected Benefits of e-HRM' positively influences 'Attitude towards using e-HRM' in Manufacturing Industry.

H4: 'Perceived Usefulness of e-HRM' positively influences 'Intention to Adopt e-HRM' in Manufacturing Industry.

H5: 'Attitude towards using e-HRM' positively influences 'Intention to Adopt e-HRM' in Manufacturing Industry.

H6: 'Expected Benefits of e-HRM' positively influences 'Intention to Adopt e-HRM' in Manufacturing Industry.

H7: 'Intention to Adopt e-HRM' positively influences 'Actual Use of e-HRM' in Manufacturing Industry.

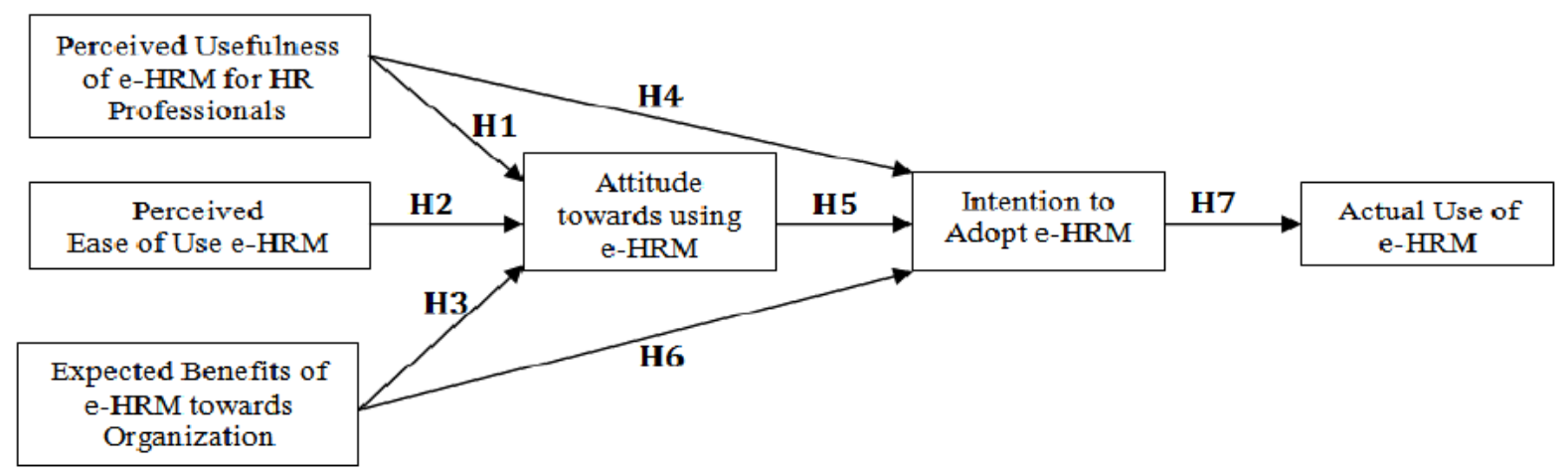

Figure 2: Hypothesized Research Model

\section{RESEARCH METHODOLOGY}

In this study, secondary data has been used to create the hypothesized research model (Figure 2) and primary data has been used to support the model. A structured questionnaire (Annexure 1) with 5 point Likert scale from 'Strongly Agree-5' to 'Strongly Disagree-1' was prepared for collecting the primary data. In this study, convenience sampling technique was used. Different types of manufacturing industries (For example, Electronic \& Electrical Equipment Manufacturing Industry, Oil \& Chemical Industry, Food Industry, Textile Industry, etc.) were selected for the collection of sample-elements. In the first stage, companies from different manufacturing industry-categories in India were selected by convenience sampling technique and responses from HR Professionals were collected from those companies through same sampling technique in the second stage. Total 200 responses were collected for this study. The survey period was from $5^{\text {th }}$ February, 2019 to $15^{\text {th }}$ April, 2019.

\section{ANALYSIS AND FINDINGS}

In this study, Structural equation modeling (SEM) through AMOS software has been used to create the research model. Also hypothesis and fitness indexes of model have been checked through Path-Analysis. Cronbach alpha value has been checked for testing the reliability of 
Intention to Adopt E-Hrm (Electronic - Human Resource Management) in Indian Manufacturing Industry: an Empirical Study Using Technology Acceptance Model (Tam)

collected primary data and the alpha value of 0.784 proves acceptable range of reliability. Exploratory Factor Analysis (EFA) through SPSS software has been used to validate the data set and extract necessary factors for this study.

Table 1: KMO and Bartlett's Test

\begin{tabular}{|c|c|c|}
\hline Kaiser-Meyer-Olkin Measure of Sampling Adequacy. & 0.680 \\
\multirow{3}{*}{$\begin{array}{c}\text { Bartlett's Test of } \\
\text { Sphericity }\end{array}$} & Approx. Chi-Square & 3246.041 \\
\cline { 2 - 3 } & Df & 105 \\
\cline { 2 - 3 } & Sig. & $<\mathbf{0 . 0 0 1}$ \\
\hline
\end{tabular}

KMO and Bartlett's Test (Table 1) proved the aptness of executing exploratory factor analysis (EFA). Total 6 factors, containing variables with 'factor loadings' more than 0.5 have been extracted through Rotated Component Matrix (Table 2) and explain total $84.197 \%$ of variance in research model.

Table 2: Result of factor analysis - Rotated Component Matrix

\begin{tabular}{|c|c|c|c|c|c|c|}
\hline \multirow[b]{2}{*}{ Variables } & \multicolumn{6}{|c|}{ Factors } \\
\hline & $\begin{array}{c}\text { Perceived Ease } \\
\text { of Use }\end{array}$ & $\begin{array}{l}\text { Expected } \\
\text { Benefits }\end{array}$ & $\begin{array}{l}\text { Perceived } \\
\text { Usefulness }\end{array}$ & $\begin{array}{l}\text { Attitude towards } \\
\text { Using }\end{array}$ & $\begin{array}{l}\text { Intention to } \\
\text { Adopt }\end{array}$ & $\begin{array}{l}\text { Actual } \\
\text { Use }\end{array}$ \\
\hline $\mathrm{q} 6$ & .966 & .046 & .049 & .103 & .000 & -.020 \\
\hline $\mathrm{q} 4$ & .950 & .057 & .062 & .115 & .044 & -.059 \\
\hline q5 & .926 & .067 & .070 & .044 & .060 & .019 \\
\hline $\mathrm{q} 8$ & .030 & .921 & .055 & .073 & .078 & -.049 \\
\hline q9 & .033 & .884 & .081 & .136 & -.060 & -.068 \\
\hline $\mathrm{q} 7$ & .097 & .861 & .011 & .103 & .025 & -.038 \\
\hline q1 & .036 & .074 & .910 & .110 & .062 & -.002 \\
\hline $\mathrm{q} 2$ & .065 & .026 & .883 & .006 & .074 & .097 \\
\hline $\mathrm{q} 3$ & .075 & .046 & .855 & .197 & -.026 & -.101 \\
\hline q11 & .114 & .157 & .132 & .932 & .189 & -.029 \\
\hline q10 & .152 & .181 & .188 & .911 & .208 & -.011 \\
\hline $\mathrm{q} 12$ & .046 & .013 & .016 & .121 & .946 & -.077 \\
\hline q13 & .043 & .022 & .086 & .229 & .920 & -.019 \\
\hline $\mathrm{q} 15$ & -.020 & .017 & .028 & -.097 & .054 & .818 \\
\hline q14 & -.022 & -.140 & -.026 & .066 & -.137 & .720 \\
\hline $\begin{array}{l}\quad \% \text { of } \\
\text { Variance } \\
\text { Explained }\end{array}$ & 18.370 & 16.449 & 16.149 & 12.606 & 12.448 & 8.174 \\
\hline
\end{tabular}

The fitness indexes (Table 3) have been checked for determining the appropriateness of research model. Also, Path Analysis has been executed for checking the influences of independent factors on dependent factors. 
Table 3: Fit indices for Research Model

\begin{tabular}{|c|c|}
\hline Fit Index with Acceptable Range & $\begin{array}{c}\text { Research Model } \\
\text { Values }\end{array}$ \\
\hline$\chi 2$ df (Values less than 3) & 0.148 \\
\hline RMSEA (Values less than 0.06) & 0.001 \\
\hline GFI (Values greater than 0.90) & 0.999 \\
\hline AGFI (Values greater than 0.90) & 0.995 \\
\hline NFI (Values greater than 0.90) & 0.998 \\
\hline CFI (Values greater than 0.90) & 0.999 \\
\hline
\end{tabular}

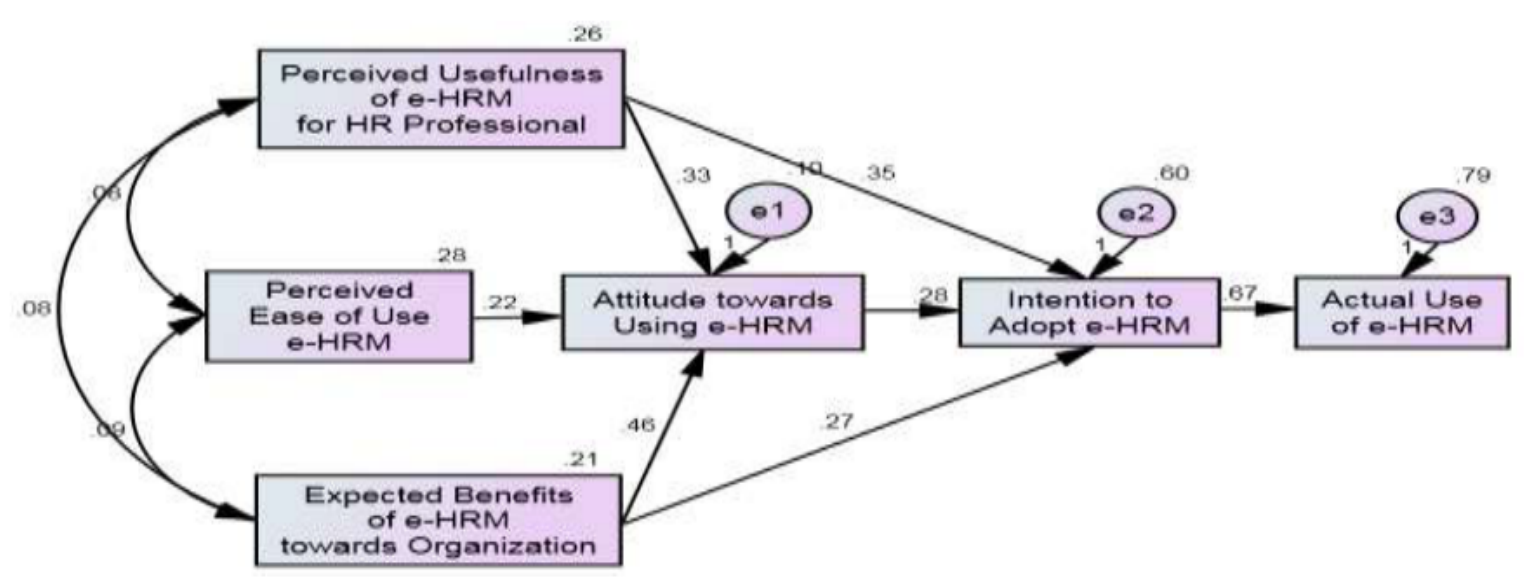

Figure 3: Output of Structural Equation Modeling

Multi-co-linearity in the research model has been checked through VIF (Variance Inflation Factor) which must be less than 3 for acceptable range and it has been observed that all VIF values (Table 4) are in acceptable range which indicates variables are free from Multi-colinearity.

Table 4: Co-linearity Statistics

\begin{tabular}{|c|c|c|c|c|c|}
\hline \multicolumn{3}{|c|}{ 'Attitude towards using e-HRM' as dependent } & \multicolumn{3}{c|}{ 'Intention to Adopt e-HRM' as dependent } \\
variable & & & Tolerance & VIF \\
\hline & Tolerance & VIF & & & 1.460 \\
\hline $\begin{array}{c}\text { Perceived Usefulness of e- } \\
\text { HRM for HR Professional }\end{array}$ & .848 & 1.179 & $\begin{array}{c}\text { Perceived Usefulness of e- } \\
\text { HRM for HR Professional }\end{array}$ & .685 & 2.169 \\
\hline $\begin{array}{c}\text { Perceived Ease of Use e- } \\
\text { HRM }\end{array}$ & .820 & 1.219 & $\begin{array}{c}\text { Attitude towards Using e- } \\
\text { HRM }\end{array}$ & .461 & 1.693 \\
\hline $\begin{array}{c}\text { Expected Benefits of e-HRM } \\
\text { towards Organization }\end{array}$ & .788 & 1.269 & $\begin{array}{c}\text { Expected Benefits of e- } \\
\text { HRM towards } \\
\text { Organization }\end{array}$ & .591 & \\
\hline
\end{tabular}


Intention to Adopt E-Hrm (Electronic - Human Resource Management) in Indian Manufacturing Industry: an Empirical Study Using Technology Acceptance Model (Tam)

Table 5: Path analysis of Research Model

\begin{tabular}{|c|c|c|c|c|c|c|c|c|}
\hline \multicolumn{2}{|c|}{ Measurement Path } & Hypothesis & Estimate & S.E. & C.R. & $\begin{array}{c}\text { P- } \\
\text { Value }\end{array}$ & Assessment \\
\hline $\begin{array}{c}\text { Attitude } \\
\text { towards } \\
\text { Using }\end{array}$ & $\leftarrow \begin{array}{c}\text { Perceived } \\
\text { Usefulness }\end{array}$ & H1 & .328 & .048 & 6.887 & $<0.01^{*}$ & Supported \\
\hline $\begin{array}{c}\text { Attitude } \\
\text { towards } \\
\text { Using }\end{array}$ & $\leftarrow$ & $\begin{array}{c}\text { Expected } \\
\text { Benefits }\end{array}$ & H3 & .460 & .055 & 8.328 & $<0.01^{*}$ & Supported \\
\hline $\begin{array}{c}\text { Attitude } \\
\text { towards } \\
\text { Using }\end{array}$ & $\leftarrow \begin{array}{c}\text { Perceived } \\
\text { Ease of Use }\end{array}$ & H2 & .216 & .046 & 4.662 & $<0.01^{*}$ & Supported \\
\hline $\begin{array}{c}\text { Intention to } \\
\text { Adopt }\end{array}$ & $\leftarrow \begin{array}{c}\text { Attitude } \\
\text { towards } \\
\text { Using }\end{array}$ & H5 & .279 & .166 & 2.682 & $0.033^{* *}$ & Supported \\
\hline $\begin{array}{c}\text { Intention to } \\
\text { Adopt }\end{array}$ & $\leftarrow \begin{array}{c}\text { Perceived } \\
\text { Usefulness }\end{array}$ & H4 & .347 & .130 & 2.662 & $0.008^{*}$ & Supported \\
\hline $\begin{array}{c}\text { Intention to } \\
\text { Adopt }\end{array}$ & $\leftarrow \begin{array}{c}\text { Expected } \\
\text { Benefits }\end{array}$ & H6 & .271 & .157 & 2.725 & $0.045^{* *}$ & Supported \\
\hline $\begin{array}{c}\text { Actual } \\
\text { Use }\end{array}$ & $\leftarrow \begin{array}{c}\text { Intention to } \\
\text { Adopt }\end{array}$ & H7 & .671 & .073 & 9.134 & $<0.01 *$ & Supported \\
\hline
\end{tabular}

\subsection{Path Analysis for Hypothesis Testing (From Figure 3 \& Table 5)}

\section{H1: 'Perceived Usefulness of e-HRM' positively influences 'Attitude towards using e- HRM' in Manufacturing Industry.}

Significant P-value $(\mathrm{p}<0.01)$ with positive $(+.328)$ path co-efficient supports the above hypothesis. A study has found out that the perception of the HR Professionals regarding the usefulness of a particular technology has a deep impact on their attitude for the adoption of that particular technology (Cakmak, et al., 2011). This study was conducted in Turkey regarding the assessment of the acceptance level of the Tax Office Automation System (VEDOP) amongst the HR Professionals. The coupling effect of perceived usefulness as well as the required positive attitude towards a particular technology leads to the development of the intention to utilise a particular technology in the optimal manner.

H2: 'Perceived Ease of Use e-HRM' positively influences 'Attitude towards using eHRM' in Manufacturing Industry.

Structural model supports the above hypothesis because path coefficient is having significant value $(\mathrm{p}<0.01)$ and expected positive sign $(+.216)$. It was addressed in the TAM model that the perceived ease of use has a significant positive relationship with the attitude level of the respondents related to the usage of the technology. TAM model has also revealed that the effect of perceived ease of use on the attitude level of the respondents can be either direct or indirect.

H3: 'Expected Benefits of e-HRM' positively influences 'Attitude towards using eHRM' in Manufacturing Industry.

Significant $\mathrm{P}$-value $(\mathrm{p}<0.01)$ with positive $(+.460)$ path co-efficient supports the above hypothesis. The information technologies used today are highly innovative in nature as they integrate numerous activities together in order to come up with a consolidated product which 
would cater to numerous works. The application of such systems would significantly increase the efficiency levels and also cut down costs (Yang, et al., 2018). Thus, the expected benefits would have a direct impact on the attitude for using the technology as well.

\section{H4: 'Perceived Usefulness of e-HRM' positively influences 'Intention to Adopt e- HRM' in Manufacturing Industry.}

Structural model supports the above hypothesis because path coefficient is having significant value $(p=0.008)$ and expected positive sign $(+.347)$. It has been seen that the perceived usefulness of the technology of the part of the respondents plays a crucial role in the development of the intention regarding the usage of the E-HRM technology.

\section{H5: 'Attitude towards using e-HRM' positively influences 'Intention to Adopt e- HRM' in Manufacturing Industry.}

Significant $P$-value $(p=0.033)$ with positive $(+.279)$ path co-efficient supports the above hypothesis. It is a well-known fact that attitude influences the behavior of a person (Reeve \& Deci, 1996). The respondents must like working with the technology, otherwise a negative perception would be developed in their minds regarding the usage of the technology which would prove detrimental to their behavioral intention of its usage.

\section{H6: 'Expected Benefits of e-HRM' positively influences 'Intention to Adopt e-HRM' in Manufacturing Industry.}

Structural model supports the above hypothesis because path coefficient is having significant value $(p=0.045)$ and expected positive sign $(+.271)$. It has been seen that the perception of the respondents regarding the beneficial aspects of the technology used plays a decisive role in the development of the intention regarding the usage of the E-HRM technology in their minds.

\section{H7: 'Intention to Adopt e-HRM' positively influences 'Actual Use of e-HRM' in Manufacturing Industry.}

Significant P-value $(\mathrm{p}<0.01)$ with positive $(+.671)$ path co-efficient supports the above hypothesis. The intention of using the technology motivates HR Professionals to use the product being given to them to develop value and also to get the work done in a specific period of time. The usage of the technology will be further promoted if the HR Professionals are satisfied with the technology in hand. The satisfaction index can be measured with the service level of the given technology. Actual use of the technology could lead to increasing productivity of the firms as the work could be done within a stipulated period of time.

\section{IMPLICATIONS}

New and innovative technology is paving the path for a new future. Due to globalisation, the human resources are under a lot of stress and pressure in order to deliver the work on time. Technology can help the human resources department of the manufacturing industries to deliver the work on time without compromising with their quality despite of their tight schedules. The growth of the HR Professionals is also focused as they are trained to use the various E-HRM technologies to get the job done within a stipulated period of time. Sending information and receiving information can also be done with the snap of a finger. Global workforce can be recruited using proper E-HRM technology and they can be compensated as well. Training and Development models can be accessible through various online portals wherein employees can $\log$ in and build their competencies in their relevant specialisations. Various extra curriculum activities could also be developed to help the employees to tackle the ever increasing work load with minimum effort. With the advent of self automation systems in the manufacturing industries, feedback is very important. It helps HR Professionals to diagnose the problems well in advance before it causes any significant error which would result in huge losses for the 
organisation. Manufacturing industry is responsible for directly contributing to the GDP of the nation. It has economic consequences as well. This industry must be developed and one of the fastest ways to do so is by adopting relevant technology to get the work done in a faster manner. E-HRM software could be used by HR Professionals in the recruitment and selection of the suitable candidates for the various job roles. The information about the employees could be stored in a centralised system so that it can be accessible for anyone in need. Thus, the adoption of the various E-HRM technologies will be having many social as well as economical results as well.

\section{CONCLUSION}

E-HRM technology enables the HR department to generate process efficiency as they have to deal with the people of the organisation on a daily basis. The people are there from all the brackets from top level management to bottom level management. This paper delves into the manufacturing industry of India and tries to find out the intention of adoption of the various EHRM technologies by HR Professionals in this particular industry. The respondents in the study have shown a positive inclination towards adopting the various technologies. The degree to which this will be done would depend on the organisation's decision for the implementation of a suitable technology that will be positively perceived by the respondents in terms of usefulness, ease of use as well as certain expected benefits. Conventional methods are becoming obsolete now and already the organisations have started relying on web based technology for getting their job done like using emails, printers, LAN network, centralised system for storing information, payment of salary with money transfer, etc. Thus, the manufacturing industry is making progress in terms of adoption of E-HRM technologies but many avenues need to be explored in the long run. Such a situation can increase the profitability of this particular industry by leaps and bounds.

\section{Annexure 1}

\begin{tabular}{|c|c|}
\hline $\begin{array}{l}\text { Facto } \\
\text { rs }\end{array}$ & Questions on different Items \\
\hline \multirow{3}{*}{$\begin{array}{l}\text { Perce } \\
\text { ived } \\
\text { Usefu } \\
\text { lness }\end{array}$} & $\begin{array}{l}\text { q1: Perceived usefulness of E-HRM technology positively influences the attitude of the HR } \\
\text { Professionals regarding its usage. }\end{array}$ \\
\hline & $\begin{array}{l}\text { q2: Perceived usefulness of the E-HRM technology positively influences the mindset of the } \\
\text { HR Professionals regarding the usage of the technology. }\end{array}$ \\
\hline & $\begin{array}{l}\text { q3: Perceived usefulness of the E-HRM technology creates an interest in the minds of the } \\
\text { HR Professionals to further explore the product. }\end{array}$ \\
\hline \multirow{3}{*}{$\begin{array}{c}\text { Perce } \\
\text { ived } \\
\text { Ease } \\
\text { of } \\
\text { Use }\end{array}$} & $\begin{array}{l}\text { q4: Perceived ease of use of E-HRM technology positively influences the attitude of the } \\
\text { HR Professionals regarding its usage. }\end{array}$ \\
\hline & $\begin{array}{l}\text { q5: Perceived ease of use of a particular E-HRM technology will help the HR Professionals } \\
\text { to clearly understand it which will help in its usage. }\end{array}$ \\
\hline & $\begin{array}{l}\text { q6: Higher levels of Perceived ease of use will help in the creation of a positive mindset of } \\
\text { the HR Professionals regarding that particular technology. }\end{array}$ \\
\hline \multirow{3}{*}{$\begin{array}{c}\text { Expe } \\
\text { cted } \\
\text { Benef } \\
\text { its }\end{array}$} & $\begin{array}{l}\text { q7: Expected benefits will help to positively influence the attitude of the HR Professionals } \\
\text { regarding the usage of the technology. }\end{array}$ \\
\hline & $\begin{array}{l}\text { q8: Expected benefits will result in the growth of the organisation by the means of adoption } \\
\text { of the E-HRM technology. }\end{array}$ \\
\hline & $\begin{array}{l}\text { q9: Expected benefits of the E-HRM technology to be adopted will result in certain social } \\
\text { and economical benefits as well. }\end{array}$ \\
\hline $\begin{array}{l}\text { Attitu } \\
\text { de }\end{array}$ & $\begin{array}{l}\text { q10: A positive attitude of the adoption of E-HRM technology will result in the } \\
\text { development of the intention to use the same. }\end{array}$ \\
\hline
\end{tabular}


Dr. Arunangshu Giri, Dr. Pradip Paul, Satakshi Chatterjee, Manigrib Bag and Abanti Aich

\begin{tabular}{|c|c|}
\hline $\begin{array}{l}\text { towar } \\
\text { ds } \\
\text { Using }\end{array}$ & $\begin{array}{l}\text { q11: Usage of the E-HRM technology must be a desirable and pleasurable experience for } \\
\text { the HR Professionals to develop a positive attitude regarding that. }\end{array}$ \\
\hline \multirow{2}{*}{$\begin{array}{l}\text { Intent } \\
\text { ion } \\
\text { to } \\
\text { Adop } \\
\text { t }\end{array}$} & $\begin{array}{l}\text { q12: Attitude for the E-HRM technology usage is responsible for the development of the } \\
\text { intention to adopt the technology. }\end{array}$ \\
\hline & $\begin{array}{l}\text { q13: Higher degree of the intention of the HR Professionals of the organisation to adopt the } \\
\text { E-HRM technology results in its actual usage. }\end{array}$ \\
\hline \multirow{2}{*}{$\begin{array}{c}\text { Actua } \\
1 \\
\text { Use }\end{array}$} & $\begin{array}{c}\text { q14: Actual usage of the E-HRM technology would make the operations very efficient and } \\
\text { effective. }\end{array}$ \\
\hline & $\begin{array}{l}\text { q15: Actual usage of the E-HRM technology would help to quantitatively measure the } \\
\text { satisfaction index of the HR Professionals through technology acceptability. }\end{array}$ \\
\hline
\end{tabular}

\section{REFERENCES}

[1] Cakmak, A. F., Benk, S., \& Budak, T, The acceptance of tax automation system (VEDOP) by employees: Factorial validation of Turkish adapted Technology Acceptance Model (TAM). International Journal of Economics and Finance. 3 (6), 2011, pp 107-117.

[2] Davis, F.D, Perceived usefulness, perceived ease of use and user acceptance of information technology. MIS Quarterly. 13(3), 1989, pp 319-340.

[3] Dosajh, B. \& Sujlana, P, New E-HRM model based on Technology Acceptance Model. Gian Jyoti E-Journal. 1(2), 2012, ISSN: 2250-348X.

[4] Gloet, M. \& Berrell, M, The dual paradigm nature of knowledge management: implications for achieving quality outcomes in human resource management. Journal of Knowledge Management. 7(1), 2003, pp $78-89$.

[5] K.R Jose and Prof. Abhijit Bhirud, Analysis of Factors Affecting Human Resource Management of Construction Firms and Probable Solutions for the Remedy of the Issues: Towards Successful Completion International Journal of Advanced Research in Engineering and Technology, 9(6), 2018, pp19-29.

[6] Ho, C-H, Continuance intention of e-learning platform: Toward an integrated model. International Journal of Electronic Business Management. 8 (3), 2010, pp 206-216.

[7] Lengnick-Hall, M.L. \& Moritz, S, The impact of e-HR on the human resource management function. Journal of Labour Research. 24(3), 2003, pp 365 - 370.

[8] Liang, G, Discussion on the application of intelligent information technology in construction engineering. China Computer \& Communication. 18, 2017, pp 31-36.

[9] Lin, L.H, Electronic human resource management and organizational innovation: the roles of information technology and virtual organizational structure. The International Journal of Human Resource Management. 22(2). 2011, pp 235-257.

[10] Reeve, J. \& Deci, E. L, Elements of the competitive situation that affect intrinsic motivation. Personality and Social Psychology Bulletin. 22 (1), 1996, pp 24-33.

[11] Robey, D, User attitudes and management information system use. Academy of Management Journal. 22 (3), 1979, pp 527-538.

[12] Swanson, E. B, Measuring user attitudes in MIS research: A review. OMEGA. 10 (2), 1982, pp 157-165.

[13] Thiruselvi, S., Yusliza, M.Y., Ramayah, T. \& Nur, Z.O, Continuance Intention usage towards E-HRM. Proceedings Book of ICEFMO, 2013, Malaysia. ISBN: 978-969-934714-6.

[14] Venkatesh, V. \& Bala, H, Technology acceptance model 3 and a research agenda on interventions. Decision Sciences. 39(2). 2008, pp 273-315. https://doi.org/10.1111/j.15405915.2008.00192.x. 
Intention to Adopt E-Hrm (Electronic - Human Resource Management) in Indian Manufacturing Industry: an Empirical Study Using Technology Acceptance Model (Tam)

[15] Venkatesh, V, Determinants of perceived ease of use: integrating control, intrinsic Motivation, and Emotion into the Technology Acceptance Model. Information Systems Research. 11(4), 2000, pp 342-365.

[16] Sunil V. Desale and Dr. S. V. Deodhar, Human Resource Management on Construction Site By Using Lean and Six Sigma Methodology, International Journal of Management (IJM), Volume 4, Issue 4, July-August (2013), pp. 131-140

[17] Dr. Govind Dave and Kirti Makwana, A Study on Assessing Expatriate's Challenges during an International Assignment: International Human Resource Management Perspective. International Journal of Marketing and Human Resource Management, 7(2), 2016, pp. $23-$ 35.

[18] Yang, Z., Wang, Y. \& Sun, C, Emerging information technology acceptance model for the development of smart construction system. Journal of Civil Engineering and Management. 24(6), 2018, pp 457-468. ISSN: 1822-3605. https://doi.org/10.3846/jcem.2018.5186.

[19] Deni Dokkaevich Saydulaev, Serge Muzalev, Nikolay Vladimirovitch Kuznetsov, Andrey Nikolaevich Zharov, Elena Anatolievna Reznik and Yulia Sergeevna Shishalova, Human Resource Management: Conflict Prevention Strategy Simulation, International Journal of Civil Engineering and Technology, 9(10), 2018, pp. 1176- 1181.

[20] K. Vijaya Sekhar Reddy, Dr. Tamarana Srinivasa Rao and Dr N. Roopalatha , An Effectiveness of Human Resource Management In Small and Medium Industries - An Telangana Experience, 8(7), 2017, pp. 1010-1017, 8(7). 